\title{
Evaluation of Wound Healing Potential of Tephrosia Purpurea (Galega Purpurea) \& In Comparision with Dexamethasone Induced Antihealing Effects in Albino Rats
}

\author{
Dr S Nagaraja Prasad ${ }^{1}$, Dr Vedavathi $\mathrm{H}^{1}$, Dr Jagadeesh $\mathrm{K}^{1}$, Dr.B.L.Kudagi ${ }^{2}$, \\ Dr B.H Nagarajaiah ${ }^{3}$, Dr Shreenivas P Revankar*1 \\ 1. Department of Pharmacology; Shivamogga Institute of Medical Sciences; Shivamogga; Karnataka-577201 \\ 2.Prof \& HOD, Narayana Institute Of Medical Sciences, Nellore,Andhra Pradesh. \\ 3. Department of Pharmacology; Mandya Institute of Medical Sciences; Mandya-Karnataka \\ *Corresponding Author:Dr Shreenivas P Revankar;Shimoga Institute Of Medical Sciences;Shimoga- \\ 577201;email;sprevankar@rediff.com;sprevankar@yahoo.com;mob:09986960012.
}

\begin{abstract}
:
Introduction: Wound healing involves number of processes which occur due to injury like coagulation, inflammation, angiogenesis, collagen deposition, epithelisation \& remodelling. Steroids have been used in various situations where wounds are prone to develop. Present study was therefore undertaken to elaborate the influence of tephrosia purpurea on wound healing as well as in dexamethasone suppressed albino rats.

Material \& Methods: Three wound screening methods were utilized for the present study; resutured incision, dead space \& excision wound screening method. Four groups consisting of 6 rats each were included in the study. Group 1 was control; group 2 was treated with tephrosia purpurea (500 $\mathrm{mg} / \mathrm{kg} /$ day). Group 3 treated with dexamethasone $0.3 \mathrm{mg} / \mathrm{kg}$ i.p per day \& group 4 received both tephrosia purpurea $(500 \mathrm{mg} / \mathrm{kg})$ \& dexamethasone $(0.3 \mathrm{mg} / \mathrm{kg})$ per day.

Results: Tephrosia purpurea reversed dexamethasone suppressed wound healing in excision, incision \& dead space wound screening methods. There was no significant improvement compared to control in incision \& dead space wound screening methods. In excision wound screening method better wound contraction \& epithelisation were recorded as compared to control group.

Analysis \& Discussion: In excision wound screening method better wound contraction \& epithelisation may be due to antioxidant \& antimicrobial properties of tephrosia purpurea. Reversal of suppressed wound healing by tephrosia purpurea may be because of better collagen deposition \& maturation influenced by flavinoids of tephrosia purpurea. Further histological \& biochemical studies are required to explain the no improvement seen in incision \& dead space wound screening methods compared to control.
\end{abstract}

Keywords: Wound Healing; Wound screening methods: Incision, Excision, Dead space, Tephrosia Purpurea, Dexamethasone.

\section{Introduction}

Wound has been defined as disruption of anatomic or functional continuity of living tissues ${ }^{1}$. Wound repair may be described as an effort to restore normal function \& structural integrity of the injured tissue ${ }^{2}$. Wound healing progresses in three phases $^{3}$ : first phase called as inflammation phase associated with inflammation(immediate 2-5 days), the second phase referred to as proliferative phase(2 days to 3 weeks) during which regeneration of tissues takes place \& the third phase called as the maturation phase( 3 weeks to 2 years) is associated with remodelling of collagen etc. There are various factors that may influence wound healing ${ }^{3}$.

General Factors:

Age, nutritional status (deficiency of vit A,C, trace elements like zinc \& cobalt) steroid intake, chronic infections eg:TB, diabetes etc.

Local Factors:

blood supply, tension \& oedema, infection, anoxia.

In allopathic medicine the introduction of antiseptic dressings by soaking lint $\&$ gauze in carbolic acid by Lister greatly revolutionised the treatment of wounds ${ }^{2}$. However in traditional system of medicine like ayurveda \& siddha various plant products have been extensively used from time immemorial for wound healing purpose. Tephrosia purpurea is one such plant advocated for treatment of chronic ulcers \& has been given the 
name of "sarva wran vishapaha" which means it has the property to cure all types of wounds ${ }^{4,5,6}$.it belongs to the family leguminosea distributed chiefly in warmer areas of Asia \& Australia ${ }^{7}$. It is said to have digestible, antihelmenthic , antipyretic properties, cure diseases of liver, spleen, heart, blood, cure ulcers, leprosy, asthma, bronchitis, roots are said to be good for ulcers \& wounds ${ }^{4}$. Initial pharmacological investigations have shown the plant to possess hepatoprotective, hypoglycaemic, hypotensive, antiallergic, analgesic, nematocidal, antibacterial \& antifungal activities. Dexamethasone is one of the longer acting fluorinated glucocorticoid, has been used for its anti-inflammatory activities in various chronic inflammatory conditions like rheumatoid arthritis, inflammatory bowel diseases or to decrease the incidence of respiratory distress in premature labour between 24-36 weeks of gestation. Various animals were used in wound healing for in vivo studies: rats $(80 \%)$, mice $(11 \%)$, guinea pigs(4\%), rabbits(4\%) etc. Of these rats are excellent for screening skin wound healing because of their ready availability, low cost $\&$ small size. Also they allow for standardization of type, size, depth of wound injury \& healing in rats occurs in days rather than weeks required in humans thus allowing early assessment of wound healing ${ }^{8}$

The present study was undertaken to evaluate the wound healing property of tephrosia purpurea \& its ability to antagonise the antihealing effects of dexamethasone in albino rats.

The following wound screening methods were utilised for the above objectives:

1. Resutured incision wound screening method $^{9,10}$.

2. Dead space wound screening method ${ }^{11}$.

3. Excision wound screening method ${ }^{12}$.

\section{Tephrosia Purpurea}

\section{Materials \& Methods}

The dried powder was obtained from Dr.B.B.Joshi, department of rasayanashastra, ayurveda mahavidyalaya, hubli, karnataka.

\section{Animals}

The animals used in present experiment work are colony bred albino rats of either sex weighing between 200-250gms obtained from the central animal house of Karnataka institute of medical sciences, hubli. The animals were maintained under standard laboratory conditions with free access to food \& water ad libitum.

\section{Groups}

Each wound screening method had four groups consisting of 6 rats each. Total of 24 rats were used during the study period.

\section{Drugs}

The dried powdered preparation of tephrosia purpurea was used both orally in a dose of $500 \mathrm{mg} / \mathrm{kg}$ body weight suspended in $2 \%$ gum acacia in incision \& dead space wound screening method as well as for topical application using autoclaved soft paraffin base in excision wound screening method. Dexamethasone $0.3 \mathrm{mg} / \mathrm{kg}$ i.p OD was used in various wound screening methods.

\section{Group 1}

$1 \mathrm{ml}$ of $2 \%$ gum acacia orally from 0 day to $10^{\text {th }}$ day in incision \& dead space wound screening method \& topically applied autoclaved soft paraffin base OD in excision wound screening method till complete epithelisation.

\section{Group 2}

Tephrosia purpurea $500 \mathrm{mg} / \mathrm{kg}$ in $2 \%$ gum acacia OD from 0 day to $10^{\text {th }}$ day in incision $\&$ dead space wound screening method while excision wound screening method was treated with tephrosia purpurea in autoclaved soft paraffin base applied topically OD till complete epithelisation.

\section{Group 3}

Inj dexamethasone $0.3 \mathrm{mg} / \mathrm{kg}$ i.p OD from 0 day to $10^{\text {th }}$ day in incision, dead space $\&$ excision wound screening method.

\section{Group 4}

Tephrosia purpurea $500 \mathrm{mg} / \mathrm{kg}$ orally OD+ dexamethasone $0.3 \mathrm{mg} / \mathrm{kg}$ OD i.p from $0-10^{\text {th }}$ day in incision $\&$ dead space wound screening method while excision wound screening method received tephrosia purpurea 
suspended in autoclaved soft paraffin base topically + dexamethasone $0.3 \mathrm{mg} / \mathrm{kg}$ i.p OD till day of complete epithelisation(time taken for the scab to fall off completely).

\section{Preparation Of Animals}

The animals were depilated at the desired site a day before wounding \& were housed individually. The animals were starved $12 \mathrm{hrs}$ prior to wounding with only free access to water. Wounding was performed under ether anaesthesia with proper precautions.

\section{Wound Screening method attributes}

The attributes studied were physical \& mechanical. Incision \& dead space wound screening methods were used to study the extent of collagenation while excision wound screening method was used to study the degree of wound contraction \& extent of epithelisation.

\begin{tabular}{|l|l|l|l|}
\hline Sl. No. & $\begin{array}{l}\text { Wound Healing Screening } \\
\text { methods }\end{array}$ & \multicolumn{1}{|c|}{ Recordings } & \multicolumn{1}{|c|}{ Post Wounding Day } \\
\hline 1 & $\begin{array}{l}\text { Excision wound screening } \\
\text { method }\end{array}$ & $\begin{array}{l}\text { Wound tracing } \\
\text { Wound photography } \\
\text { Epithelisation time. }\end{array}$ & $\begin{array}{l}0,4,8,12, \text { and } 16^{\text {th }} \text { day } \\
0,4,12 \text { and } 16^{\text {th }} \text { day } \\
\text { Time taken for falling of scab without raw area. }\end{array}$ \\
\hline 2 & $\begin{array}{l}\text { Incision wound screening } \\
\text { method strength }\end{array}$ & $\begin{array}{l}\text { Suture removal } \\
\text { Wound breaking day } \\
\text { measurement. } \\
\text { th day. }\end{array}$ \\
\hline 3. & $\begin{array}{l}\text { Dead space screening } \\
\text { method foreign body } \\
\text { granuloma) }\end{array}$ & $\begin{array}{l}\text { Granuloma } \\
\text { strength }\end{array}$ & $10^{\text {th }}$ day. \\
\hline
\end{tabular}

\section{Excision Wound Method:}

Under ether anaesthesia, the animal was secured to the operation table in prone position. An impression was made on the dorsal interscapular region over the skin in between the two ears, by using a round seal of 2.5 $\mathrm{cm}$ diameter as described by marton and malone ${ }^{12}$. The skin of the impressed area was excised to the full thickness to obtain a wound area of about approximately 500 sq.mm. Haemostasis was achieved by blotting the wound with cotton swab soaked in normal saline.

The physical attributes of healing namely, wound contraction, epithelisation time were studied in this model. Contraction which mainly contributes for wound closure in the first two weeks was studied by tracing the raw wound area on transparent polythene paper on wounding day, followed by $4^{\text {th }}, 8$ th, 12 th and $16^{\text {th }}$ day . Fall of scab without any raw wound area was noted as the time taken for complete epithelisation. Wound healing was monitored by planimetry that is by retracing the wound from polythene paper onto a millimetre scale graph paper and then the numbers of squares were counted.

The mean percentage of closure and S.D were calculated. The number of days for complete epithelisation was noted as the time taken for fall of scab without any raw wound area.

\section{Resutured Incision Wound Screening Method:}

Under ether anaesthesia the animal was secured to operation table in its natural position. Two paravertebral incisions of $6 \mathrm{cms}$ each were made through the entire thickness of the skin on either side of vertebral column with the help of sharp surgical blade as described by Ehrlich and Hunt ${ }^{9}$. The incisions were made $1 \mathrm{~cm}$ lateral to the vertebral column. After complete haemostasis achieved by use of blotting paper, the wounds were closed by means of interrupted sutures placed about $1 \mathrm{~cm}$ apart using 4-zero silk thread. Wounds were then mopped with cotton swabs soaked in 70\% alcohol and animals were caged individually. The sutures were removed on the $8^{\text {th }}$ post-wounding day and breaking strength was determined on $10^{\text {th }}$ post-wounding day by continuous, constant water flow technique of Lee ${ }^{13}$ as described below.

Anaesthetised animal was secured to operation table in its natural position and lines were drawn on either side of the incision wound, $3 \mathrm{~mm}$ away from the wound margin on adjacent normal skin leaving $5 \mathrm{~mm}$ wound on both sides. Two allis's forceps were firmly applied on the lines, facing each other; the forceps on one side was fixed to a metal rod, while the other forceps was attached to a light polythene container through a thread run over a pulley. Then water was allowed to flow at a constant rate into the polythene container so as to build a gradual pulling force necessary to disrupt the wound. The flow of water was regulated by means of a rubber clamp connected to water reservoir, kept at a suitable height. As soon as gaping of wound was observed, the water flow was cut off. Further opening of the wound was avoided by lifting the polythene container. 
The volume of water in the polythene container was measured and converted to corresponding weight, assuming the density to be equal to one. The breaking strength is expressed as the minimum weight of water necessary to bring about gaping of wound. Three such readings were recorded for a given incision wound and the procedure was repeated on the other side, thus obtaining six readings for each animal. The mean breaking strength for each animal was used to calculate the group mean.

\section{Dead Space Wound Screening Method ${ }^{11}$}

Under ether anaesthesia, subcutaneous dead space wounds were inflicted in the region of axilla, by making a pouch through a small nick in skin. Granuloma formation was induced by implanting sterile grass piths measuring $2.5 \mathrm{~cm}$ in length and $0.2 \mathrm{~cm}$ in diameter. The wounds were sutured and mopped with alcoholic swab and animals were placed into their individual cages after recovery from anaesthesia.

Excision of the granuloma from the surrounding tissue was performed on the $10^{\text {th }}$ post-wounding day under ether anaesthesia.

Granuloma surrounding the grass piths was slit open by longitudinal incision in one plane so as to obtain rectangular strips. The breaking strength of a piece measuring about $1.5 \mathrm{~cm}$ in length and $8 \mathrm{~mm}$ in width (obtained by trimming the rectangular strip of granuloma tissue) was measured, by employing the method described under incision wounds.

Excision, incision \& dead space wound screening method results obtained were analysed by ANOVA followed by unpaired t test.

\section{Excision Wound Screening method:}

\section{Results}

The various parameters measured were:

1) Percentage closure of original wound area (500 sq mm).

2) Time taken for complete epithelisation.

$\%$ of wound contraction=(initial wound area - specific day wound area) X 100/ Initial wound area

\section{Observations}

$4^{\text {th }}$ day: percentage wound closure (mean \pm s.d) (table no.1 graph 1)

Group i : $18.59 \pm 0.61$; group ii: $21.18 \pm 0.70$;group iii: $3.26 \pm 0.72$;group iv: $19.19 \pm 0.90$.

Intergroup comparison revealed that the percentage of wound contraction was highly significant $(\mathrm{p}<0.001)$ when group ii was compared to group i and group iv compared to group iii.

$\mathbf{8}^{\text {th }}$ day: percentage wound closure (mean \pm s.d) (table no2 graph 1)

Group i: $70.97 \pm 1.36$;group ii: $80.56 \pm 0.93$;group iii: $15.38 \pm 1.48$;group iv: $24.08 \pm 1.21$.

Intergroup comparison revealed that the percentage of wound contraction was highly significant $(\mathrm{p}<0.001)$ in group ii compared to group $\mathrm{i}$ and in group iv compared to group iii.

$\mathbf{1 2}^{\text {th }}$ day: percentage closure ( mean \pm s.d) (table no3, graph 1$)$

Group i: $81.03 \pm 1.48$; group ii:91.90 \pm 0.60 ;group iii: $46.95 \pm 1.36$; group iv: $75.39 \pm 0.90$.

Intergroup comparison revealed a highly significant $(\mathrm{p}<0.001)$ wound contraction in group ii compared to group $\mathrm{i}$ and in group iv compared to group iii.

$\mathbf{1 6}^{\text {th }}$ day: percentage wound contraction (mean \pm s.d) (table no4, graph 1)

Group i: $90.28 \pm 0.83$; group ii: $93.15 \pm 0.74$; group iii: $73.17 \pm 0.97$;group iv: $83.76 \pm 0.88$

Intergroup comparison revealed a highly significant $(\mathrm{p}<0.001)$ wound contraction in group ii compared to group $i$ and in group iv compared to group iii.

\section{Time (In Days) Taken For Complete Epithelisation (Mean \pm Sd)(Table No 6; Graph2)}

Group i: $20.00 \pm 1.41$;group ii: $18.00 \pm 0.89$;group iii: $23.17 \pm 0.75$;group iv:20.00 \pm 2.10 .

Intergroup comparison revealed significant reduction in time taken $(\mathrm{p}<0.01)$ for complete epithelisation when group ii compared to group i. Also the time taken for epithelisation of group iv animals was significantly reduced $(\mathrm{p}<0.001)$ when compared to group iii.

\section{Granuloma Screening Method:}

The breaking strength (gms) of granuloma was measured on $10^{\text {th }}$ day and the results are as follows (table no.7, graph 3):

Group i: $201.67 \pm 16.94$; group ii : $204.17 \pm 17.12$; group iii:123.67 \pm 11.20 ; group iv:202.67 \pm 13.37 . 
Evaluation of wound healing potential of tephrosia purpurea (galega purpurea) \& in comparision...

Intergroup comparison of the results showed no significant difference $(p>0.05)$ in breaking strength of group ii compared to group i. However the breaking strength of group iv was highly significant $(\mathrm{p}<0.001)$ when compared to group iii.

\section{Resutured Incision Wound Screening Method:}

The breaking strength (g) was (mean \pm s.d) as follows (table no8, graph 4 ):group i:304.67 \pm 12.09 ;group

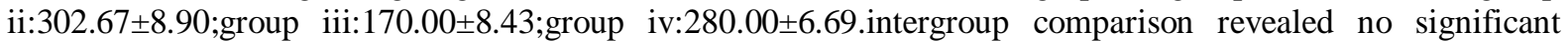
difference $(\mathrm{p}>0.05)$ between group ii and group i. However the breaking strength of group iv was highly significant $(\mathrm{p}<0.001)$ when compared to group iii.

Table 1: Percentage Closure Of Excision Wound Area(Sq.Mm) On $4^{\text {th }}$ Postwounding Day.

\begin{tabular}{|l|l|l|l|l|}
\hline $\begin{array}{l}\text { Animal } \\
\text { Number }\end{array}$ & $\begin{array}{l}2 \% \text { Gum } \\
\text { Acacia } \\
\text { (Group i) }\end{array}$ & $\begin{array}{l}\text { Tephrosia } \\
\text { Purpurea } \\
\text { (Group ii) }\end{array}$ & $\begin{array}{l}\text { Dexamethasone } \\
\text { (Group iii) }\end{array}$ & $\begin{array}{c}\text { Tephrosia Purpurea } \\
+ \\
\text { Dexamethasone(Groupiv) }\end{array}$ \\
\hline 1 & 18.34 & 20.31 & 4.09 & 18.2 \\
\hline 2 & 18.29 & 21.75 & 3.13 & 20.24 \\
\hline 3 & 18.39 & 21.61 & 2.48 & 18.69 \\
\hline 4 & 19.81 & 21.87 & 4.14 & 18.34 \\
\hline 5 & 18.16 & 21.17 & 2.57 & 20.08 \\
\hline 6 & 18.56 & 20.35 & 3.14 & 19.60 \\
\hline Mean \pm S.D & $18.59 \pm 0.61$ & $21.18 \pm 0.70$ & $3.26 \pm 0.72$ & $19.19 \pm 0.90$ \\
\hline
\end{tabular}

$\mathrm{F}=753.74 ; \mathrm{P}<0.001$.

\section{Unpaired student t test:}

A. Group ii compared to Group i:t $=6.80 ; \mathrm{P}<0.001$

B. Group iv compared to Group iii: $\mathrm{t}=34.48 ; \mathrm{P}<0.001$.

Table 2:Percentage Closure Of Excision Wound Area(Sq.Mm) On $8^{\text {th }}$ Post Woundingday

\begin{tabular}{|l|l|l|l|l|}
\hline Animal Number & $\begin{array}{l}2 \% \text { Gum Acacia } \\
\text { (Group i) }\end{array}$ & $\begin{array}{l}\text { Tephrosia } \\
\text { Purpurea } \\
\text { (Group ii) }\end{array}$ & $\begin{array}{l}\text { Dexamethasone } \\
\text { (Group iii) }\end{array}$ & $\begin{array}{l}\text { Tephrosiapurpurea } \\
+ \\
\text { Dexamethasone(Group iv) }\end{array}$ \\
\hline 1 & 72.21 & 79.88 & 17.35 & 23.29 \\
\hline 2 & 72.95 & 79.22 & 14.68 & 23.77 \\
\hline 3 & 70.92 & 80.56 & 14.12 & 24.45 \\
\hline 4 & 69.81 & 81.31 & 17.16 & 22.29 \\
\hline 5 & 69.48 & 80.58 & 14.85 & 25.15 \\
\hline 6 & 70.45 & 81.80 & 14.12 & 25.54 \\
\hline Mean \pm S.D & $70.97 \pm 1.36$ & $80.56 \pm 0.93$ & $15.38 \pm 1.48$ & $24.08 \pm 1.21$ \\
\hline
\end{tabular}

$\mathrm{F}=403.9 ; \mathrm{P}<0.01$.

\section{Unpaired students t test:}

Group ii compared to Group i:t=14.26; $\mathrm{P}<0.001$.

Group iv compared to Group iii: $\mathrm{t}=11.148 ; \mathrm{P}<0.001$.

Table 3:Percentage Closure Of Excision Wound Area(Sq.Mm)On $12^{\text {th }}$ Postwounding Day

\begin{tabular}{|c|c|c|c|c|}
\hline $\begin{array}{c}\text { Animal } \\
\text { Number }\end{array}$ & $\begin{array}{c}\text { Gum Acacia } \\
\text { (Group i) }\end{array}$ & $\begin{array}{c}\text { Tephrosia Purpurea } \\
\text { Group ii) }\end{array}$ & $\begin{array}{c}\text { Dexamethasone } \\
\text { (Group iii) }\end{array}$ & $\begin{array}{c}\text { Tephrosiapurpurea } \\
+ \\
\text { Dexamethasone(Group iv) }\end{array}$ \\
\hline 1 & 81.85 & 91.60 & 48.93 & 74.95 \\
\hline 2 & 82.48 & 92.43 & 46.38 & 76.42 \\
\hline 3 & 78.80 & 91.36 & 46.40 & 73.35 \\
\hline 4 & 80.75 & 92.05 & 48.32 & 75.44 \\
\hline 5 & 82.40 & 91.26 & 46.14 & 76.24 \\
\hline 6 & 79.92 & 92.76 & 45.50 & $75.39 \pm 0.90$ \\
\hline
\end{tabular}

$\mathrm{F}=1699.9 ; \mathrm{P}<0.001$.

Unpaired students $\mathbf{t}$ test

A.Group ii compared to Group i:t=16.67; $\mathrm{P}<0.001$.

B.Group iv compared to Group iii :t=42.95; $\mathrm{P}<0.001$.

Table 4:Percentage Closure Of Excision Wound Area (Sq.Mm) On $16^{\text {th }}$ Post Wounding Day

\begin{tabular}{|l|l|l|l|l|}
\hline Animal Number & $\begin{array}{l}2 \% \text { Gum } \\
\text { Acacia } \\
\text { (Group i) }\end{array}$ & $\begin{array}{l}\text { Tephrosia } \\
\text { Purpurea } \\
\text { (Group ii) }\end{array}$ & $\begin{array}{l}\text { Dexamethasone } \\
\text { (Group iii) }\end{array}$ & $\begin{array}{l}\text { Tephrosiapurpurea } \\
+ \\
\text { Dexamethasone(Group iv) }\end{array}$ \\
\hline
\end{tabular}


Evaluation of wound healing potential of tephrosia purpurea (galega purpurea) \& in comparision...

\begin{tabular}{|l|l|l|l|l|}
\hline 1 & 90.17 & 92.58 & 73.88 & 83.17 \\
\hline 2 & 91.43 & 93.79 & 72.60 & 84.29 \\
\hline 3 & 90.81 & 92.34 & 74.16 & 83.70 \\
\hline 4 & 90.00 & 93.44 & 73.96 & 82.45 \\
\hline 5 & 88.95 & 92.62 & 72.67 & 84.02 \\
\hline 6 & 90.34 & 94.13 & 71.76 & 84.95 \\
\hline Mean \pm S.D & $90.28 \pm 0.83$ & $93.15 \pm 0.74$ & $73.17 \pm 0.97$ & $83.76 \pm 0.88$ \\
\hline
\end{tabular}

$\mathrm{F}=642.09 ; \mathrm{P}<0.001$.

Unpaired students $\mathbf{t}$ test

A. Group ii compared to Group i: $\mathrm{t}=6.36$; $\mathrm{P}<0.001$.

B. Group iv compared to Group iii: $\mathrm{t}=19.81$; $\mathrm{P}<0.001$.

Table 5: Percentage Closure Of Excision Wound Area (Sq.mm) At Different Time Intervals (Mean \pm S.D) In Various Groups

\begin{tabular}{|l|l|l|l|l|}
\hline Day & 2\% Gum Acacia(Group i) & $\begin{array}{l}\text { Tephrosia Purpurea } \\
\text { (Group ii) }\end{array}$ & $\begin{array}{l}\text { Dexamethasone } \\
\text { (Group iii) }\end{array}$ & $\begin{array}{l}\text { Tephrosiapurpurea } \\
\text { +Dexamethasone } \\
\text { (Group iv) }\end{array}$ \\
\hline 4 & $18.59 \pm 0.61$ & $21.18 \pm 0.70$ & $3.26 \pm 0.72$ & $19.19 \pm 0.90$ \\
\hline 8 & $70.97 \pm 1.36$ & $80.56 \pm 0.93$ & $15.38 \pm 1.48$ & $24.08 \pm 1.21$ \\
\hline 12 & $81.03 \pm 1.48$ & $91.90 \pm 0.60$ & $46.95 \pm 1.36$ & $75.39 \pm 0.90$ \\
\hline 16 & $90.28 \pm 0.83$ & $93.15 \pm 0.74$ & $73.17 \pm 0.97$ & $83.76 \pm 0.88$ \\
\hline
\end{tabular}

Table 6: Time Taken For Complete Epithelisation (Days)

\begin{tabular}{|l|l|l|l|l|}
\hline $\begin{array}{l}\text { Animal } \\
\text { Number }\end{array}$ & $\begin{array}{l}2 \% \text { Gum Acacia } \\
\text { (Group i) }\end{array}$ & $\begin{array}{l}\text { Tephrosia } \\
\text { Purpurea } \\
\text { (Group ii) }\end{array}$ & $\begin{array}{l}\text { Dexamethasone } \\
\text { (Group iii) }\end{array}$ & $\begin{array}{l}\text { Tephrosiapurpurea } \\
\text { +Dexamethasone } \\
\text { (Group iv) }\end{array}$ \\
\hline 1 & 20 & 19 & 23 & 22 \\
\hline 2 & 18 & 17 & 24 & 18 \\
\hline 3 & 19 & 18 & 22 & 20 \\
\hline 4 & 21 & 18 & 24 & 23 \\
\hline 5 & 22 & 19 & 23 & 19 \\
\hline 6 & 20 & 17 & 23 & 18 \\
\hline Mean \pm S.D & $20.00 \pm 1.41$ & $18.00 \pm 0.89$ & $23.17 \pm 0.75$ & $20.00 \pm 2.10$ \\
\hline
\end{tabular}

$\mathrm{F}=14.099 ; \mathrm{P}<0.05$.

\section{Unpaired students t test}

Group ii compared to Group i: $\mathrm{t}=2.93 ; \mathrm{P}<0.01$.

Group iv compared to Group iii: $\mathrm{t}=3.48 ; \mathrm{P}<0.001$.

Table 7: Breaking Strength(gms) Of Granuloma Tissue On $10^{\text {th }}$ Post Wounding Day

\begin{tabular}{|l|l|l|l|l|}
\hline Animal Number & $\begin{array}{l}2 \% \text { Gum Acacia } \\
\text { (Group i) }\end{array}$ & $\begin{array}{l}\text { Tephrosia } \\
\text { Purpurea } \\
\text { (Group ii) }\end{array}$ & $\begin{array}{l}\text { Dexamethasone } \\
\text { (Group iii) }\end{array}$ & $\begin{array}{l}\text { Tephrosiapurpurea }+ \\
\text { Dexamethasone } \\
\text { (Group iv) }\end{array}$ \\
\hline 1 & 206 & 236 & 124 & 180 \\
\hline 2 & 218 & 205 & 118 & 196 \\
\hline 3 & 186 & 192 & 132 & 212 \\
\hline 4 & 224 & 188 & 120 & 204 \\
\hline 5 & 192 & 206 & 140 & 218 \\
\hline 6 & 184 & 198 & 108 & 206 \\
\hline MEAN \pm S.D & $201.67 \pm 16.94$ & $204.17 \pm 17.12$ & $123.67 \pm 11.20$ & $202.67 \pm 13.37$ \\
\hline
\end{tabular}

$\mathrm{F}=42.559 ; \mathrm{P}<0.001$

\section{Unpaired students t test}

Group ii compared to Group i: $t=0.25 ; \mathrm{P}>0.05$

Group iv compared to Group iii :t=11.09; $\mathrm{P}<0.001$.

Table 8: Breaking Strength (gms)Of Resutured Incision Wound On $10^{\text {th }}$ Post Wounding Day

\begin{tabular}{|l|l|l|l|l|}
\hline Animal Number & $\begin{array}{l}2 \% \text { Gum Acacia } \\
\text { (Group i) }\end{array}$ & $\begin{array}{l}\text { Tephrosia Purpurea } \\
\text { (Group ii) }\end{array}$ & $\begin{array}{l}\text { Dexamethasone } \\
\text { (Group iii) }\end{array}$ & $\begin{array}{l}\text { Tephrosiapurpurea } \\
\text { +Dexamethasone } \\
\text { (Group iv) }\end{array}$ \\
\hline 1 & 285 & 295 & 160 & 278 \\
\hline 2 & 305 & 298 & 174 & 286 \\
\hline 3 & 320 & 308 & 168 & 282 \\
\hline 4 & 312 & 310 & 184 & 270 \\
\hline 5 & 298 & 315 & 172 & 288 \\
\hline 6 & 308 & 290 & 164 & 276 \\
\hline MEAN \pm S.D & $304.67 \pm 12.09$ & $302.67 \pm 8.90$ & $170.00 \pm 8.43$ & $280.00 \pm 6.69$ \\
\hline
\end{tabular}

$\mathrm{F}=287.01 ; \mathrm{P}<0.01$. 


\section{Unpaired students $\mathbf{t}$ test}

Group ii compared to Group i:t $=0.32 ; \mathrm{P}>0.05$.

Group iv compared to Group iii: $=25.03 ; \mathrm{P}<0.001$.
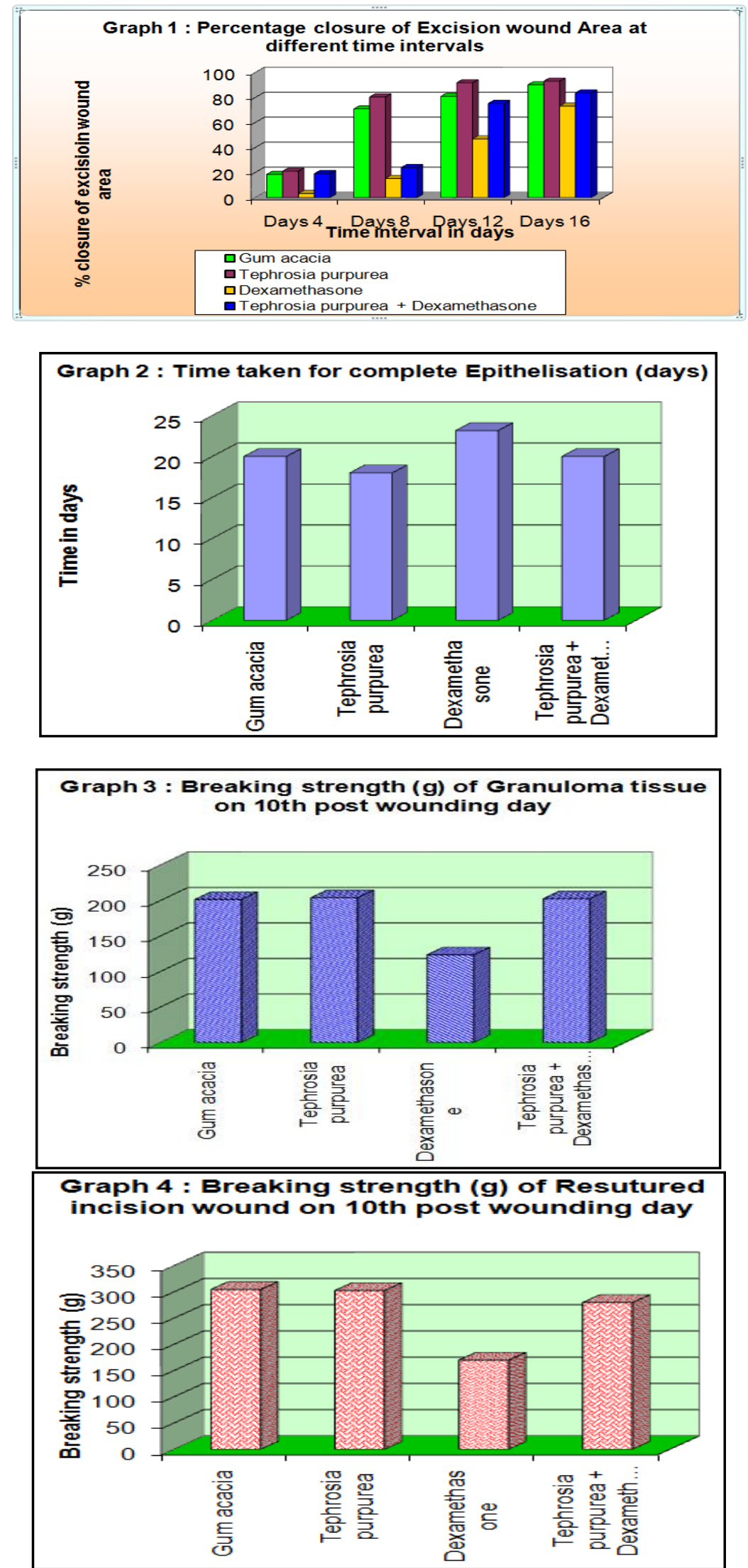


\section{Discussion}

Wound healing involves various processes occurring concurrently \& no single wound healing screening method is sufficient to assess the influence of various factors on all aspects of wound healing, therefore in the present study three commonly used wound screening methods viz incision, dead space \& excision wound screening methods were utilized.

One of the important parameters studied during wound healing is the breaking strength of the wound. It is well known that breaking strength of scar tissue is approximately $3 \%$ after one week \& $20 \%$ of its final strength at 3 weeks. At the end of three months although it regains $80 \%$ of its original strength the scar always remains weaker than normal dermis ${ }^{3}$. Various factors are known to inhibit wound healing: infection, ischemia, diabetes mellitus, ionizing radiation, advanced age, malnutrition, vitamin deficiencies (vit a \& c), mineral deficiencies (zinc, iron) \& drugs like glucocorticoid. If the bacterial counts in wounds exceed $10^{5}$ organisms per gram of tissue or if $\beta$ haemolytic streptococci are present the wound will not heal by any means, thus even infection plays an important role in delayed wound healing. Also glucocorticoids have been shown to inhibit gene transcription \& thus impair fibroblast proliferation \& collagen synthesis, the amount of granulation tissue formed is also decreased ${ }^{2}$.

An analysis of phytochemical constituents of tephrosia purpurea reveals the presence of flavinoids as important constitutents. ${ }^{14,15}$. Tephrosia purpurea may act via its antioxidant mechanisms to improve viability of collagen fibres by affecting the maturation \& organization of newly formed collagen fibrils ${ }^{16}$ as observed by increase in wound breaking strength after administration of tephrosia purpurea in dexamethasone treated groups. Also flavinoids of tephrosia purpurea have been found to have antimicrobial properties which are reflected in better wound contraction \& early epithelisation in tephrosia purpurea treated group as compared to control in excision wound screening method. Hence tephrosia purpurea has got the potential to improve wound healing especially suppressed by dexamethasone.

Note: This was a preliminary study of role of tephrosia purpurea \& further studies to estimate the hydroxyproline content of the healing wound tissue would shed more light into the exact mechanisms of improved wound healing in dexamethasone suppressed wound screening method \& why it did have much effect in comparison to control group in incision \& dead space wound screening methods.

\section{Acknowledgement}

We are thankful to the principal \& director of Karnataka institute of medical sciences, Hubli for providing the necessary research facilities for this study.

\section{References}

[1]. Schilling J A. Wound Healing. Physiological Rev.1968; 48:p375-423.

[2]. Courtney M.Townsend. Wound Healing In Sabiston's: Textbook Of Surgery-The Biological Basis Of Modern Surgical Practice Saunders (Elsevier Publications) 2008,18 ${ }^{\text {th }}$ Ed Vol1; p191-216.

[3]. Anil Srivatsava, Sunil Chabner Wounds In Essentials Of Surgery Sunil Chabner, Jaypee Publications $2005,1^{\text {st }}$ Ed p105.

[4]. Kirtikar K.R, Basu B.D Eds Indian Medicinal Plants, $2^{\text {nd }}$ Ed Delhi: Periodical Experts Book Agency, 1991:p723-726.

[5]. Yoganarasimhan S.N. Medicinal Plants of India Vol 2. Bangalore: Cyber Media;2000:p536-537.

[6]. Deshpande S, Shah G.B, Parmar N.S. Antiulcer Activity of Tephrosia Purpurea In Rats. Indian Journal of Pharmacology 2003, 35:p168-172.

[7]. Gokhale B.B, Saraf M.N. Tephrosia Purpurea: A Review Of Contemporary Literature \& Medicinal Properties. Indian Drugs 2000; 37(12): p553-560

[8]. Wanda A Dorsett-Martin \& Annette B Wysacki. Rat Models Of Skin Wound Healing. Sourcebook Of Models For Biomedical Research. P.M.Conn, Ed 2008 Humana Press Inc. Totowa NJ p631-638.)

[9]. Ehrlich H.P, Hunt T.K. Effect Of Cortisone \& Anabolic Steroids On Tensile Strength Of Healing Wound. Ann Surg 1969; 170: p203-206.

[10]. Ehrlich H.P, Hunt T.K. Effect Of Cortisone \& Vit A On Wound Healing. Ann Surg 1968;167: p324-328.

[11]. Patel P.A, Kulkarni D.R. Effect Of Antiproliferative Agents On Healing Of Dead Space Wounds In Rats. Ind J Med Res 1984; 79 : p445-447.

[12]. Morton J J , Malone M.H. Evaluation Of Vulnerary Activity By An Open Wound Procedure In Rats. Arch Int Pharmacodyn 1972; 196:p117-126.

[13]. Lee K.H. Studies on the Mechanism of Action Of Salicylates Iii. Retardation Of Wound Healing By Aspirin. J Pharm Sci 1968; 57:p1238-1240.

[14]. Raj Narayana K, Sripal Reddy H, Chaluvadi M.R. Bioflavonoid: Classification, Pharmacological, Biochemical Effects \& Therapeutic Potential. Indian Journal Ofpharmacology.2001; 33:p 2-16.

[15]. Robert J Nijveldt, Els Van Nood, Danny Ec Van Hoorn, Petra G Boelens, Klaske Van Norren, And Paul Am Van Leeuwen. Flavinoids: A Review Of Probable Mechanisms Of Action And Potential Applications. Am J Clin Nutr Oct 2001; 74(4):p418-425.

[16]. Shobha S Nadig, Gurumadhwa Rao.S Effect Of Hepatogard- An Indigenous Formulation On Dexamethsone Induced Antihealing Effects In Male Albino Rats. Indian J Physiol Pharmacol 1999; 43(2):p230-234. 